\title{
Peningkatan Pengetahuan tentang Penyakit Jantung Koroner
}

\author{
Ambar Dwi Erawati \\ Email: ambarerawati@gmail.com \\ Program Studi Informatika Medis, Universitas Widya Husada Semarang, Indonesia \\ J1. Subali Raya No 12 Krapyak Semarang \\ Telp. (024) 7612988
}

\begin{abstract}
Abstrak
Penyakit yang terjadi pada lansia paling banyak terjadi adalah hipertensi. Sedangkan Hipertensi memiliki faktor resiko $81,3 \%$ terjadi penyakit jantung koroner. Penyakit Jantung Koroner dapat dicegah dengan pola hidup yang sehat, sehingga perlu dilakukan peningkatan pengetahuan tentang penyakit jantung koroner pada lansia. Metode untuk meningkatkan pengetahuan tentang penyakit jantung koroner dengan melalui ceramah yang merupakan rangkaian kegiatan pengabdian masyarakat Pendampingan kader posyandu lansia di RW V Kelurahan Bambankerep Kecamatan Ngaliyan Kota Semarang. Hasilnya mengalami peningkatan sebanyak 39,1\% tentang definisi, $21,73 \%$ tentang tanda gejala, $28,3 \%$ tentang faktor resiko dan $28,3 \%$ pada pencegahan penyakit jantung koroner.
\end{abstract}

Kata Kunci: jantung koroner; peningkatan; pengetahuan.

\begin{abstract}
The disease that occurs in the elderly is hypertension. Meanwhile, hypertension has $81.3 \%$ risk factors for coronary heart disease. Coronary heart disease can be prevented with a healthy lifestyle, so it is necessary to increase knowledge about coronary heart disease in the elderly. Methods to increase knowledge about coronary heart disease through lectures which are a series of community service activities Assistance for elderly posyandu cadres in RW V, Bambankerep Village, Ngaliyan District, Semarang City. The results increased by $39.1 \%$ regarding definition, $21.73 \%$ regarding signs and symptoms, $28.3 \%$ regarding risk factors and $28.3 \%$ regarding the prevention of coronary heart disease
\end{abstract}

Keywords: coronary heart; improvement; knowledge.

\section{Pendahulauan}

Saat ini ada beberapa definisi mengenai lansia, menurut UndangUndang No.13 tahun 1998 tentang kesejahteraan lanjut usia adalah seseorang yang usianya mencapai 60 tahun[1]. Pada saat lansia mengalami penuaan dengan mengalami penurunan secara biologis maupun psikologis[2].

Jumlah Lansia di Kota Semarang pada tahun 2018 sebesar 156,9 atau $8,78 \%$, hal tersebut meningkat sekitar $1 \%$ dari tahun sebelumnya Usia harapan Hidup Lansia[3]
Pada Lansia rentan terkena infeksi penyakit menular karena mengalami penurunan fungsi fisiologis. Sesuai dengan hasil Riskesdas 2013,

penyakit terbanyak pada lanjut usia adalah Penyakit Tidak Menular (PTM) antara lain hipertensi, artritis, stroke, Penyakit Paru Obstrukf Kronik (PPOK) dan Diabetes Mellitus (DM)[4].

Lansia dengan hipertensi memiliki faktor resiko terjadinya penyakit jantung koroner. Sesuai dengan penelitian yang dilakukan oleh Karyatin yang berjudul "FaktorFaktor Yang Berhubungan Dengan 
Kejadian Penyakit Jantung Koroner" yaitu pada penderita hipertensi sebanyak $81,3 \%$ mengalami penyakit jantung koroner[5].

Berdasarkan Riskesdes 2018, kematian akibat penyakit jantung koroner mengalami peningkatan yaitu sebanyak $1,5 \%$ yang tadinay berdasarkan Riskesdes 2013 hanya sebanyak $0,5 \%[6]$.

Penyakit Jantung Koroner adalah gangguan pada fungsi jantung karena penyempitan pada pembuluh darah koroner atau arteri koroner yang dapat dicegah dengan pola hidup sehat[7]. Sesuai dengan penelitian yang dilakukan oleh (Bakta, I Nyoman, 2014) yang berjudul " hubungan antara pengetahuan dan sikap terhadap perilaku Pemberantasan Sarang Nyamuk (PSN) sebagai pencegahan DBD di Banjar Badung, Desa Melinggih wilayah Puskesmas Payangan" bahwa ada hubungan antara pengetahuan terhadap perilaku pencegahan penyakit DBD[8]. Pengetahuan yang didapatkan dari penyuluhan merupakan pengetahuan eksplisit[9]. Oleh karena itu perlu diberi informasi tentang penyakit jantung koroner dan deteksi dini terjadinya penyakit jantung koroner bagi Lansia di RW V Kelurahan Bambankerep.

Tujuan kegiatan ini adalah untuk menilai keberhasilan kegiatan penyuluhan tentang penyakit jantung koroner di Kelurahan Bambankerep Kota Semarang.

\section{Metode}

Kegiatan peningkatan pengetahuan tentang penyakit jantung koroner merupakan salah satu rangkaian kegiatan pengabdian masyarakat yang dilakukan penulis dalam kegiatan program Kemitraan pada Kader Posyandu di RW V Kelurahan Bambankerep Kecamatan Ngaliyan. Dalam kegiatan tersebut dilakukan penyuluhan tentang deteksi dini penyakit Jantung Koroner pada Lansia di RW V Kelurahan Bambankerep Kecamatan Ngaliyan Kota Semarang. Jumlah Lansia yang Hadir pada kegiatan tersebut sebanyak 46 Lansia. Penilaian dilakukan secara serempak kepada lansia dengan membagikan kuisener pre test dan post test yang disbarkan oleh mahasiswa pada saat penyuluhan

\section{Hasil dan Pembahasan}

Peningkatan pengetahuan tentang Penyakit Jantung Koroner dilakukan pada tanggal 5 Maret 2020, di Rumah Ketua RW V Kelurahan Bambankerep dengan jumlah lansia yang hadir sebanyak 46 lansia. Kegiatan yang dilakukan untuk meningkatkan pengetahuan lansia tentang penyakit jantung koroner dengan memberikan penyuluhan tentang definisi, tanda gejala, faktor resiko dan pencegahan penyakit jantung koroner .

\section{Gambar. Penulis melakukan penyuluhan}

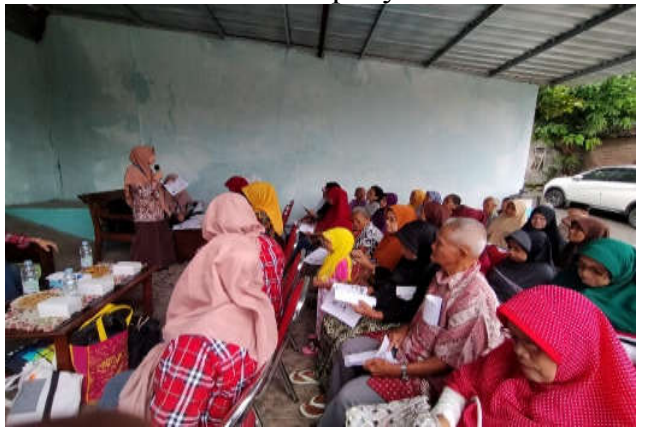

Keberhasilan kegiatan peningkatan pengetahuan tenang penyakit jantung koroner terlihat pada tabel berikut. 
Tabel peningkatan pengetauan tentang jantung koroner

\begin{tabular}{lcccc}
\hline \multicolumn{1}{c}{ Pernyataan } & Pre test & Post test & Peningkatan \\
\hline Definisi Penyakit Jantung Koroner & $\mathbf{5 6 , 2} \%$ & $\mathbf{9 5 , 7 \%}$ & $\mathbf{3 9 , 1 \%}$ \\
\hline Tanda gejala Penyakit Jantung Koroner & $\mathbf{7 8 , 3 \%}$ & $\mathbf{1 0 0} \%$ & $\mathbf{2 1 , 7 3 \%}$ \\
\hline $\begin{array}{l}\text { Faktor Resiko Penyakit Jantung } \\
\text { Koroner }\end{array}$ & $\mathbf{7 1 , 7} \%$ & $\mathbf{1 0 0} \%$ & $\mathbf{2 8 , 3 \%}$ \\
\hline \begin{tabular}{l} 
Pencegahan Penyakit Jantung Koroner \\
\hline
\end{tabular} & $\mathbf{6 7 , 4 \%}$ & $\mathbf{9 5 , 7 \%}$ & $\mathbf{2 8 , 3 \%}$ \\
\hline
\end{tabular}

Dari tabel diatas terlihat ada perubahan pengetahuan tentang Penyakit Jantung Koroner berupa peningkatan dimana pengetahuan tentang definisi meningkat sebanyak $39,1 \%$, pengetahuan tentang tanda gejala meningkat $21,73 \%$, peningkatan tentang faktor resiko sebanyak $28,3 \%$ dan peningkatan tentang pencegahan penyakit jantung koroner sebanyak $28,3 \%$.

Hal tersebut sesuai dengan teori yang disampaikan Gordon B Davis bahwa dengan informasi membantu menambah pengetahuan dan mengurangi ketidak pastian pemakai informasi[10]. Dengan diberi informasi tentanng penyakit jantung koroner, lansia di RW V mengalami peningkatan pengetahuannya tentang penyakit jantung koroner .

Melihat data yang diperoleh dari pre dan post tes menunjukan peningkatan pengetahuan akan tetapi jika melihat pre test saja sebenarnya para lansia sudah banyak yang tahu tentang penyakit jantung koroner. Akan tetapi perlu ditingaktkan terus dan perlu di terapkan dalam kehidupan sehari-hari untuk lebih paham. Hal tersebut sesuai dengan teori (Nitechi 1985) bahwa pengetahuan adalah sebuah proses yang bersambung secara terus menerus[11]

\section{Kesimpulan}

Kegiatan

peningkatan pengetahuan tentang penyakit jantung koroner pada lansia memberi dampak yang baik yaitu terjadi peningkatan pengetahuan tentang penyakit jantung koroner pada lansia di RW V Kelurahan Bambankerep Kecamatan Ngaliyan Kota Semarang. Yaitu peningkatan sebanyak $39,1 \%$ tentang definisi, $21,73 \%$ tentang tanda gejala, $28,3 \%$ tentang faktor resiko dan $28,3 \%$ pada pencegahan penyakit jantung koroner

\section{Daftar Pustaka}

[1] K. N. R. Indonesia, 'UndangUndang Republik Indonesia Nomor 13 Tahun 1998 Tentang Kesejahteraan Lanjut Usia', Kementriann Negara Republik Indonesia, vol. 1, no. 071116072. p.7, 1998.

[2] B. Stanley, Buku Ajar Keperawatan Gerontik. Jakarta: EGC, 2007.

[3] D. of P. and C. A. Semarang, Total Population of Semarang City. 2020.

[4] P. D. dan I.- Kementrian Kesehatan, Situasi Lanjut Usia (Lansia) di Indonesia. 2016. 
[5] K. Karyatin, 'Faktor-Faktor Yang Berhubungan Dengan Kejadian Penyakit Jantung Koroner', $J$. Ilm. Kesehat., vol. 11, no. 1, pp. 37-43, 2019.

[6] B. K. dan P. M. K. K. RI., 'Transisi Pola Hidup Sebabkan Peningkatan Kasus Penyakit Jantung, in Kementerian Kesehatan republik Indonesia, 2019.

[7] R. F. Yulanda, 'Kamus Penyakit Jantung Koroner', Good Doctor, jakarta, 2020.

[8] N. N. Y. K. Bakta and I. M. Bakta, 'Hubungan Antara Pengetahuan Dan Sikap Terhadap Perilaku Pemberantasan Sarang Nyamuk (PSN) Sebagai Pencegahan Demam Berdarah Dengue (DBD) Di Banjar Badung, Desa Melinggih, Wilayah Puskesmas Payangan Tahun 2014', E-Jurnal Med. Udayana, vol. 4, no. 6, pp. 1-12, 2015.

[9] Wilkipedia, 'Pengetahuan', Wilkipedia. 2020.

[10] Jeperson Hutahaean, Konsep Sistem Informasi. Deepublish, 2015.

[11] S. Ati, Nurdien, Kistanto, and A. Taufik, Pengantar Konsep Informasi, Data, dan Pengetahuan. 2014. 